\title{
A RETROSPECTIVE 5 YEAR STUDY OF PPTCT PROGRAMME AT TERTIARY CARE CENTRE
}

K. Saritha ${ }^{1}$, P. Himabindu², G. L. Shobitha ${ }^{3}$, M. Vasudha ${ }^{4}$

\section{HOW TO CITE THIS ARTICLE:}

K. Saritha, P. Himabindu, G. L. Shobitha, M. Vasudha. "A Retrospective 5 Year Study of PPTCT Programme at Tertiary Care Centre". Journal of Evolution of Medical and Dental Sciences 2015; Vol. 4, Issue 46, June 08; Page: 8000-8008, DOI: 10.14260/jemds/2015/1163

ABSTRACT: BACKGROUND: Mother to child transmission of HIV is a major cause of paediatric HIV. MTCT prevention strategies include comprehensive antenatal, postnatal and paediatric health services, voluntary counselling and testing (VCT), antiretroviral prophylaxis; counselling and support for safe infant feeding and optimal obstetrical practices. OBJECTIVES: The present retrospective study is undertaken to evaluate the effectiveness of implementation of PPTCT Programme in a tertiary care hospital. METHODOLOGY: All pregnant women attending antenatal OP and labour room were counselled and tested for HIV. All positive patients were again counselled and ART therapy started. Spouses of all positive women counselled and tested. Modification of labour and delivery practices was followed. All the babies born to positive mothers received Nevirapine prophylaxis and babies were tested at 6,12 and 18 months. Mothers were counselled regarding breast feeding and tubectomy was advised for all patients. RESULTS: A total number of 36113 antenatal women counselled and $\mathbf{9 7 . 9 0 \%}$ of them gave consent for testing. Seropositivity in these women was $0.91 \%$. Most of these patients were primi or second gravida, majority of them were young, belonging to age group of $20-24$ yrs. $61.84 \%$ of spouses were found to be seropositive. Most of these women (67.72\%) were delivered through vaginal route. LSCS was done for obstetric indication in $32.27 \%$ of cases. Majority of mothers opted for replacement feeding (78.96\%). Seropositivity of babies born to these mothers was 3.07\%.This has shown downward trend from 2010 to 2015. CONCLUSIONS: The PPTCT programme is effective and has reduced the rate of transmission from mother to child and with present triple drug therapy a further reduction is expected.

KEYWORDS: PPTCT, HIV, ART, Nevirapine.

INTRODUCTION: An estimated 2.1 million (2011) are positive for HIV with a prevalence of $0.27 \%$ of these women constitute $39 \%$ of PLHIV and children less than 15 years constitute $7 \%$ of all infections. ${ }^{1}$ Vertical or mother to child transmission is the major route of transmission for children. This can occur transplacentally in the uterus during pregnancy, perinatally during the process of labour and delivery and postnatally during breast feeding. Since July 2010 Universal HIV screening has been included as an integral component of routine antenatal check-up. Without any intervention the risk of transmission of HIV from infected pregnant women to her children is estimated to be around $20-45 \%$ during pregnancy, delivery and breast feeding.

Use of ART and single dose of Nevirapine (NVP)/syrup NVP to mother baby pairs during labour reduced the transmission to as low as $10 \%$. However it does not reduce the risk of transmission during antenatal and breastfeeding periods.

Providing lifelong ART for all pregnant and breastfeeding women living with HIV in which they receive a triple drug ART regimen regardless of CD4 count or WHO stage has the potential to reduce the risk of mother to child transmission to less than 5\%. 


\section{ORIGINAL ARTICLE}

The aim of this retrospective study is to evaluate the effectiveness of PPTCT programme implementation at Tertiary Medical College Hospital for the period between April 2010-March 2015.

MATERIAL AND METHODS: This is a retrospective study conducted at the department of Obstetrics \& Gynecology, Siddhartha Medical College from April 2010-March 2015 for a period of 5 years. The material was obtained from the PPTCT centre and from the individual case records maintained by the Medical records department of our institute.

Since the establishment of PPTCT centre in the antenatal outpatient the routine protocol followed is group counselling of all pregnant women where in antenatal care and the precautions to be taken, diet to be taken by the pregnant women are explained to them. Along with routine injections to be taken, iron and folic acid tablets are distributed to them. They are informed about the modes of spread of HIV virus and the adequate safety measures to be adopted to prevent the HIV virus from infecting them if they test negative. Consent is taken for HIV test and blood samples are collected. Post-test counselling is done and information regarding avoidance of the infection is given. Women testing positive are seen by the counsellors after confirmation by 3 rapid tests. The spouse and other existing children of the couple are tested for HIV. CD4 cell count is done for the positive women and single dose NVP to mother and NVP syrup to baby administered from April 2010 to August 2012. ART prophylaxis is initiated for the women regardless of the trimester of pregnancy and CD4 count and WHO stage from September 2012 to March 2015.

Known HIV positive cases and already on ART, ART is continued. HIV negative women are again tested as per guidelines for window period and H/o risk exposure. All women are counselled for institutional deliveries.

All unbooked cases, who reported with labour pains, are screened for HIV. If found positive ART is started irrespective of CD4 count. From April 2010 to August 2012 single dose of Nevirapine was given to all positive cases of HIV in labour irrespective of the fact whether they were already on ARV/ART prophylaxis or admitted as unbooked cases in labour and found to be HIV positive. From September 2012 to January 2014 triple drug ARV prophylaxis with 3 drugs Tenofovir (TDF) 300 mg+Lamivudine $300 \mathrm{mg}$ (3TC)+Efavirenz $600 \mathrm{mg}$ was started for women with CD4 less than 350 from 14 weeks pregnancy and continued throughout breast feeding period. From January 2014 the same drugs are initiated and continued even though the woman is in the first trimester of pregnancy. All positive pregnant women lifelong ART with above drugs continued for lifelong irrespective of CD4 count and staging. ${ }^{1}$

During labour the risk of mother to child is increased by prolonged rupture of membranes. Hence artificial rupture of membranes was avoided, routine episiotomy was not done and instrumental delivery was minimized. If indicated low cavity outlet forceps was applied.

Caesarean section was performed only for obstetric indications. ART was given prior to operation if not started earlier and continued thereafter. Early clamping of umbilical cord was done for vaginal delivery as well as operative delivery.

All babies received Nevirapine prophylaxis immediately after birth and were advised exclusive breast feeding (EBF) for 6 months. Exclusive replacement feeding (ERF) was allowed but only on condition that they fulfilled the A (Affordable), F (Feasible), A (Acceptable), S (Sustainable), S (Safe) criteria.

For infants weighing less than $2 \mathrm{~kg}$ Nevirapine dose is. $2 \mathrm{ml} / \mathrm{kg}, 2-2.5 \mathrm{~kg} 1 \mathrm{ml} / \mathrm{kg},>2.5 \mathrm{~kg} 1.5$ $\mathrm{ml} / \mathrm{kg}$ as a single dose. Daily NVP is given for 6 weeks for both EBF and ERF babies. 


\section{ORIGINAL ARTICLE}

At the end of 6 weeks dry blood samples of babies' blood is sent for HIV testing. If positive whole blood sample is tested by 3 rapid tests, if this is positive then infant is initiated on paediatric ART. The babies were tested at 6 months, 12 months and finally at 18 months. If HIV positivity is confirmed during the tests, they were started on paediatric ART. If mother is unbooked and found to be positive and started ART during labour, then NVP prophylaxis given to baby till 12 weeks. Final confirmation of HIV status of baby was done at 18 months by doing all 3 rapid tests.

Spouse testing and counselling was done for spouses of women with positive report. Of the positive women some have opted for medical termination of pregnancy. On completion of child bearing tubectomy was advised to all positive women.

RESULTS: The data collected from PPTCT programme of our institute. The data is tabulated and results are as follows:

\begin{tabular}{|c|c|c|c|c|c|c|}
\hline Year & $\begin{array}{c}\text { Number Antenatal } \\
\text { cases counselled }\end{array}$ & $\begin{array}{c}\text { Number } \\
\text { Tested }\end{array}$ & $\begin{array}{c}\text { Antenatal } \\
\text { positives }\end{array}$ & $\begin{array}{c}\text { Labour ward } \\
\text { tested }\end{array}$ & $\begin{array}{c}\text { LW } \\
\text { Positives }\end{array}$ & $\begin{array}{c}\text { Positive } \\
\text { Deliveries }\end{array}$ \\
\hline $2010-11$ & 7570 & 7362 & $112(1.52 \%)$ & 373 & 0 & 139 \\
\hline $2011-12$ & 7350 & 7111 & $83(1.16 \%)$ & 180 & 0 & 155 \\
\hline $2012-13$ & 6184 & 6054 & $59(0.97 \%)$ & 177 & 1 & 136 \\
\hline $2013-14$ & 7390 & 7301 & $43(0.59 \%)$ & 252 & 1 & 114 \\
\hline $2014-15$ & 7619 & 7528 & $23(0.31 \%)$ & 424 & 0 & 88 \\
\hline Total & $\mathbf{3 6 1 1 3}$ & $\begin{array}{c}\mathbf{3 5 3 5 6} \\
\mathbf{( 9 7 . 9 0 \% )}\end{array}$ & $\begin{array}{c}\mathbf{3 2 0} \\
\mathbf{( 0 . 9 1 \% )}\end{array}$ & $\mathbf{1 4 0 6}$ & $\mathbf{2}$ & $\mathbf{6 3 2}$ \\
\hline
\end{tabular}

Table 1: Year wise Antenatal women tested, seropositive and positive deliveries

\begin{tabular}{|c|c|c|c|c|c|}
\hline Year & $\begin{array}{c}\text { Total number } \\
\text { of +ve } \\
\text { Deliveries }\end{array}$ & $\begin{array}{c}\text { No. of } \\
\text { Vaginal } \\
\text { deliveries }\end{array}$ & $\begin{array}{c}\text { No. } \\
\text { of LSCS }\end{array}$ & $\begin{array}{c}\text { No. } \\
\text { opted } \\
\text { for } \\
\text { MTP }\end{array}$ & $\begin{array}{c}\text { No. opted } \\
\text { for } \\
\text { sterilization }\end{array}$ \\
\hline $2010-11$ & 139 & 89 & 50 & 15 & 49 \\
\hline $2011-12$ & 155 & 112 & 43 & 18 & 65 \\
\hline $2012-13$ & 136 & 90 & 46 & 10 & 25 \\
\hline $2013-14$ & 114 & 77 & 37 & 9 & 27 \\
\hline $2014-15$ & 88 & 60 & 28 & 2 & 25 \\
\hline Total & $\mathbf{6 3 2}$ & $\mathbf{4 2 8 ( 6 7 . 7 2 \% )}$ & $\mathbf{2 0 4}(\mathbf{3 2 . 2 7} \%)$ & $\mathbf{5 4}$ & $\mathbf{1 9 1}$ \\
\hline \hline
\end{tabular}

\begin{tabular}{|c|c|c|c|c|}
\hline Year & $\begin{array}{c}\text { No. of } \\
\text { Live births }\end{array}$ & $\begin{array}{c}\text { Still } \\
\text { births }\end{array}$ & IUD & $\begin{array}{c}\text { Up to 18 } \\
\text { month deaths }\end{array}$ \\
\hline $2010-11$ & $139^{*}$ & 0 & 1 & 11 \\
\hline $2011-12$ & 155 & 0 & 0 & 14 \\
\hline $2012-13$ & 136 & 0 & 0 & 8 \\
\hline $2013-14$ & 109 & 2 & 3 & 7 \\
\hline $2014-15$ & 81 & 4 & 3 & 7 \\
\hline Total & $\mathbf{6 2 0}(\mathbf{9 7 . 9 4 \% )}$ & $\mathbf{6 ( 0 . 9 4 \% )}$ & $\mathbf{7 ( 1 . 1 1 \% )}$ & $\mathbf{4 7 ( 7 . 5 8 \% )}$ \\
\hline
\end{tabular}

Table 3: Delivery outcome of seropositive antenatal women

*twins. 


\section{ORIGINAL ARTICLE}

\begin{tabular}{|c|c|c|c|c|c|c|c|}
\hline Year & $\begin{array}{c}\text { No. of +ve } \\
\text { Deliveries }\end{array}$ & $\begin{array}{c}\text { Primi } \\
\text { gravida }\end{array}$ & $\begin{array}{c}\text { Gravida } \\
\text { II }\end{array}$ & $\begin{array}{c}\text { Gravida } \\
\text { III }\end{array}$ & $\begin{array}{c}\text { Gravida } \\
\text { IV }\end{array}$ & $\begin{array}{c}\text { Gravida } \\
\text { V }\end{array}$ & $\begin{array}{c}\text { Gravida } \\
\text { VI }\end{array}$ \\
\hline $2010-11$ & 139 & 77 & 53 & 8 & 1 & 0 & \\
\hline $2011-12$ & 155 & 64 & 65 & 21 & 4 & 0 & 1 \\
\hline $2012-13$ & 136 & 70 & 51 & 11 & 4 & & - \\
\hline $2013-14$ & 114 & 47 & 54 & 12 & 0 & 1 & \\
\hline $2014-15$ & 88 & 45 & 35 & 7 & 1 & 0 & \\
\hline TOTAL & $\mathbf{6 3 2}$ & $\begin{array}{c}\mathbf{3 0 3} \\
\mathbf{( 4 7 . 9 4 \% )}\end{array}$ & $\begin{array}{c}\mathbf{2 5 8} \\
\mathbf{( 4 0 . 8 2 \% )}\end{array}$ & $\begin{array}{c}\mathbf{5 9} \\
\mathbf{( 9 . 3 3 \% )}\end{array}$ & $\begin{array}{c}\mathbf{1 0} \\
\mathbf{( 1 . 5 8 \% )}\end{array}$ & $\mathbf{1}$ & $\mathbf{1}$ \\
$\mathbf{( 0 . 1 5 8 \% )}$ & $\mathbf{( 0 . 1 5 8 \% )}$ \\
\hline
\end{tabular}

Table 4: Gravida wise distribution of Seropositive women

\begin{tabular}{|c|c|c|c|c|c|}
\hline Year & $\begin{array}{c}\text { No. of +ve } \\
\text { Deliveries }\end{array}$ & $\mathbf{1 5 - 1 9 Y r s}$ & $\mathbf{2 0 - 2 4 Y r s}$ & $\mathbf{2 5 - 3 4 Y r s}$ & >35Yrs \\
\hline $2010-11$ & 139 & 16 & 78 & 43 & 2 \\
\hline $2011-12$ & 155 & 6 & 84 & 61 & 4 \\
\hline $2012-13$ & 136 & 8 & 103 & 24 & 1 \\
\hline $2013-14$ & 114 & 7 & 83 & 20 & 4 \\
\hline $2014-15$ & 88 & 7 & 64 & 16 & 1 \\
\hline TOTAL & $\mathbf{6 3 2}$ & $\mathbf{4 4 ( 6 . 9 6 \% )}$ & $\mathbf{4 1 2 ( 6 5 . 1 9 \% )}$ & $\mathbf{1 6 4 ( 2 5 . 9 5 \% )}$ & $\mathbf{1 2 ( 1 . 8 9 \% )}$ \\
\hline \multicolumn{7}{|c|}{ Table 5: Age wise distribution of Seropositive women } \\
\end{tabular}

\begin{tabular}{|c|c|c|c|}
\hline Year & $\begin{array}{c}\text { No. of +ve } \\
\text { Deliveries }\end{array}$ & $\begin{array}{c}\text { No. opted for } \\
\text { Breast feeding }\end{array}$ & $\begin{array}{c}\text { No. opted for } \\
\text { replacement feeding }\end{array}$ \\
\hline $2010-11$ & 139 & 0 & 139 \\
\hline $2011-12$ & 155 & 2 & 153 \\
\hline $2012-13$ & 136 & 14 & 122 \\
\hline $2013-14$ & 114 & 72 & 42 \\
\hline $2014-15$ & 88 & 45 & 43 \\
\hline TOTAL & $\mathbf{6 3 2}$ & $\mathbf{1 3 3 ( 2 1 . 0 4 \% )}$ & $\mathbf{4 9 9 ( 7 8 . 9 6 \% )}$ \\
\hline
\end{tabular}

Table 6: Year wise distribution of Feeding options

\begin{tabular}{|c|c|c|c|c|}
\hline Year & $\begin{array}{c}\text { ANC } \\
\text { Positive }\end{array}$ & $\begin{array}{c}\text { No. Spouses } \\
\text { counselled }\end{array}$ & $\begin{array}{c}\text { No. Spouses } \\
\text { tested }\end{array}$ & $\begin{array}{c}\text { No. Spouses } \\
\text { +ve }\end{array}$ \\
\hline $2010-11$ & 112 & 69 & 69 & $47(68.11 \%)$ \\
\hline $2011-12$ & 83 & 58 & 58 & $34(58.62 \%)$ \\
\hline $2012-13$ & 59 & 51 & 51 & $29(56.86 \%)$ \\
\hline $2013-14$ & 43 & 31 & 31 & $22(66.67 \%)$ \\
\hline $2014-15$ & 23 & 20 & 19 & $9(45 \%)$ \\
\hline TOTAL & $\mathbf{3 2 0}$ & $\mathbf{2 2 9 ( 7 1 . 5 6 \% )}$ & $\mathbf{2 2 8 ( 9 9 . 5 6 \% )}$ & $\mathbf{1 4 1 ( 6 1 . 8 4 \% )}$ \\
\hline
\end{tabular}




\section{ORIGINAL ARTICLE}

\begin{tabular}{|c|c|c|c|}
\hline Year & $\begin{array}{c}\text { No. of +ve live } \\
\text { Deliveries }\end{array}$ & $\begin{array}{c}\text { No. of babies } \\
\text { tested }\end{array}$ & $\begin{array}{c}\text { No. of seropositive } \\
\text { babies }\end{array}$ \\
\hline $2010-11$ & 139 & 78 & $6(7.69 \%)$ \\
\hline $2011-12$ & 155 & 98 & $6(6.12 \%)$ \\
\hline $2012-13$ & 136 & 136 & $1(0.73 \%)$ \\
\hline $2013-14$ & 114 & 109 & $1(0.92 \%)$ \\
\hline $2014-15$ & 88 & 68 & $1(1.47 \%)$ \\
\hline $2010-2015$ & 632 & 489 & $15(3.07 \%)$ \\
\hline \multicolumn{4}{|c}{ Table 8: Seropositivity in babies } \\
\hline
\end{tabular}

DISCUSSION: The rate of perinatal transmission without intervention is $19-36 \% .^{2}$ It occurs during prenatal, intranatal and postnatal periods. The rate of transmission during each period is important for the development of protective measures. 25-35\% of transmission occurs during the prenatal period, mainly in late pregnancy. $375 \%$ of total transmission occurs during labour. Postnatal transmission occurs via breast milk and accounts for $10-16 \%$ of transmission. ${ }^{4}$ MTCT prevention strategies include comprehensive antenatal, postnatal and paediatric health services, voluntary counselling and testing (VCT), antiretroviral prophylaxis; counselling and support for safe infant feeding and optimal obstetrical practices

Mother to child transmission of HIV is a major cause of paediatric HIV. Out of an estimated 27 million pregnancies in a year only about $52.7 \%$ attend health services for skilled care during child birth in India. Of those who availed health services 8.83 million ANC received HIV counselling and testing (March 2013). Out of which 12, 551 pregnant women detected to be HIV positive.

In our study between 2010-11 to 2014-15 a total of 36113 antenatal patients were counselled and 35356 antenatal patients consented for testing with acceptance rate of $97.90 \%$.Majority of these patients were young between 20 to 24 years with a mean age of 23.36 yrs. Majority of these patients were primi and second gravida. HIV seroprevalence rate in antenatal cases in our study found to be 0.91 percent $(0.31$ to $1.52 \%)$. In India it ranges from $1-5.9 \%$. In a study conducted by Pawan M.Ukey, it was found to be $1.38 \%$, whereas Potharaju Jayanthi et al reported a range from $0.6-1.6 \% .5,6$ The number positive deliveries exceeded the number of positive antenatal cases because large number of positive cases referred from peripheral centers for deliveries.

In developing countries like India, it was believed that husbands were mostly responsible for transmission of HIV in mothers through the sexual route and therefore, they are considered to be equally responsible for the transmission of HIV to their children. In India therefore, PMTCT is termed as PPTCT (Prevention of parent-to-child transmission) so that mothers alone should not be blamed for HIV in their children.

In our study we have not offered preconception counselling. The Centers for Disease Control and Prevention (CDC), the American College of Obstetrics and Gynecology (ACOG), and other national organizations recommend offering preconception counselling and care as a component of routine primary medical care to all women of childbearing age. The purpose of preconception care is to improve the health of each woman prior to conception by identifying risk factors for adverse maternal or foetal outcome, providing education and counselling targeted to the patient's individual needs, and treating or stabilizing medical conditions to optimize maternal and foetal outcomes. 


\section{ORIGINAL ARTICLE}

All the spouses of 320 seropositive women were offered counselling but only $229(71.56 \%)$ spouses attended counselling and 228 spouses gave consent for testing with an acceptance rate of $99.56 \%$. Out of seropositive 320 pregnant women only $71.25 \%$ of spouses only were tested, which is higher than reported by Potharaju Jayanthi et al. Seropositivity of spouses in our study was 61.84\%, our results are comparable to other study. ${ }^{6}$ Seropositivity is less in spouses of antenatal women indicating that there are a high percentage of discordant couples. During the post-test counselling for the couple emphasis is laid on using condoms for the male. Of the seropositive women the 54 women opted for medical termination of pregnancy. The 191 women opted for tubectomy in our study $(30.22 \%)$. Other children of seropositive women were tested and most of these multigravida's earlier children were HIV negative.

Mother to child transmission risk is maximum during labour and delivery. The proposed mechanisms for intrapartum transmission are uterine contractions during labour that are responsible for micro-transfusion from constant massage of the placental bed and during labour exposure of the baby's mucocutaneous surface to maternal blood and cervical secretions. ${ }^{2}$

Modification of obstetric procedures performed in these patients, artificial rupture of membranes (for 4 or more hours before delivery), foetal scalp electrode for intra-partum foetal monitoring, instrumental delivery and episiotomy are associated with significant increases in MTCT and should be avoided. Some recommended practices include cleansing the birth canal with dilute antiseptic solutions, minimization of the number of vaginal examinations, dividing the umbilical cord under the cover of gauze pack, cleaning the baby immediately after delivery with dilute antiseptic solution, as well as strict observance of universal precaution in the labour ward.7,8,9,10,11,12

Mode of delivery of delivery by vaginal route in most of the cases (67.72\%). and LSCS was performed only for obstetric indications in $32.27 \%$ of cases Our results are comparable with other studies.6,13 Other authors reported When the viral load is more than $1000 \mathrm{copies} / \mathrm{ml}$, elective c/s significantly reduces MTCT. When the viral load is lower than 1000 copies/ml, Caesarean section confers no additional advantage to the infant. Emergency Caesarean section after the membranes have ruptured is associated with increased risk of MTCT.7,8,9,11

Some authors recommended appropriate prophylaxis for opportunistic infections, especially in women with low CD4 cell count levels, improves the foetal and maternal outcomes of pregnancy and is recommended. Cotrimoxazole prophylactic therapy should be offered when the CD4 cell count is $<350 / \mathrm{ml} 3 .^{7}$ We have not administered any prophylactic antibiotics in our study.

HIV virus is transmitted through breast milk. Breast milk and accounts for $10-16 \%$ of transmission. The breast milk of HIV-infected mothers contains proviral HIV and free virus, as well as protective factors such as HIV antibodies and a glycoprotein that inhibits HIV binding to CD4+ cells. ${ }^{13,14}$ Avoidance of breastfeeding completely eliminates this risk and is the recommended practice in the advanced countries. NACO guidelines recommend exclusive breast feeding for 6 months in a resource poor country like India. Continued breastfeeding for up to 12 months with ARV cover, and introduction of complementary feeds from the age of 6 months. ${ }^{15,6}$ This is believed to be associated with the highest rate of HIV-free survival in the resource-restricted countries.

The number of women accepting breast feeding in our study was $21.04 \%$ and $78.96 \%$ the number of women opted for exclusive replacement feeding. The women were advised to top feed only if the AFASS criteria were fulfilled. The acceptance rate of breast feeding is increasing in the recent years. 


\section{ORIGINAL ARTICLE}

From April 2010 to August 2012 patients in the present study received $200 \mathrm{mg}$ of Nevirapine along with syrup Nevirapine to the babies. From September 2012 to March 2015 for all the HIV+ve women ART was started during pregnancy whenever they were reported positive, if they are not on ART. In our study $3.07 \%$ of babies were seropositive. There was definite reduction in the number of babies tested positive after 18 months belongs to mothers who are on ARV/ART prophylaxis. There is paucity of data at 18 months due to babies migrating and getting tested at another centre or due to other adverse outcomes.

The woman living with HIV and the members of her family need a number of care and support services. These include medical care, family planning, screening and treatment of opportunistic infections, nutritional supplementation, psychosocial and spiritual support, and community-based care services, among others. These services are usually not all located at one site so that effective referral and linkages are necessary and should be in place. ${ }^{7}$

CONCLUSION: The strategies for PMTCT have proved very effective in preventing MTCT of HIV and thus the paediatric positive cases. Sero prevalence in this study is $3.07 \%$ and the heartening aspect is the decreasing trend seen across 5 years. This is due to the effective implementation of PPTCT programme. The majority of women were in the 19-24 years age group, followed by 25-29 years group. This could be because this is the most sexually active group. High prevalence in this group causes a great financial burden as well as loss of youth for the country. The number positive deliveries exceeded the number of positive antenatal cases because large number of positive cases referred from peripheral centers for deliveries.

Another disturbing factor is the number of discordant couples in this study with less number of males compared to females being positive.

Initiation of ARV/ART on confirmation of positive status of the women and nevirapine to infants expected bring down number of positive cases.

ACKNOWLEDGEMENT: We acknowledge the cooperation extended by Mrs. Roja and other staff of PPTCT centre of our Hospital for providing necessary data.

\section{REFERENCES:}

1. Updated guidelines for prevention of parent to child transmission of HIV using multidrug antiviral regimen in India. www.naco.gov.in/-/National guidelines-for PPTCT.pdf Feb 182014 Chapter 1.

2. Surjushe A, Maniar J. Prevention of mother-to-child transmission. Indian J Dermatol Venerol Leprol 2008; 74: 200-7.

3. Ehrnst A, Lindgren S, Dictor M. HIV in Pregnant Women and their Offspring: Evidence for Late Transmission. Lancet 1991; 338: 203-7.

4. Nduati R, John G, Mbori-Ngacha D, Richardson B, Overbaugh J, Mwatha A, et al. of breastfeeding and formula feeding on transmission of HIV-1: A randomized clinical trial. JAMA 2000; 283: 1167-74.

5. Pawan M. Ukey, Suresh L, Akulwar, Rajaram M. Powar. Seroprevalence of human immune deficiency infection in pregnancy in a tertiary care hospital. Indian J Med Sci 2005; 59 (9): 382387. 


\section{ORIGINAL ARTICLE}

6. Potharaju Jayanthi, P. V. Raghava Rao. "Prevention of Parent to Child Transmission of HIV: A Retrospective Study of 5 Years in a Tertiary Centre, Guntur, South India”. J of Evolution of Med and Dent Sci 2015; 4 (13): 2067-2072.

7. Nkwo. Prevention of mother to child transmission of human immunodeficiency virus: The Nigerian perspective. Ann Med Health Sci Res 2012; 2: 56-65.

8. WHO New data on Prevention of Mother to child transmission of HIV and their policy implications, conclusions and recommendations. WHO technical consultation on behalf of the UNFPA/UNICEF/WHO/UNAIDS inter-agency Task Team on mother to child transmission of HIV, Geneva. 11-13 Oct.2000. Geneva. World Health Organization. 2001; WHO/RHR/01-28.

9. Perinatal HIV Guideline Working Group, Public Health Services Task force Recommendations for Use of Antiretroviral Drugs in pregnant HIV infected women for maternal health and interventions to reduce perinatal HIV transmission in the United States. February 2005.

10. Committee on Obstetric practice. ACOG committee on scheduled caesarean delivery and prevention of vertical transmission of HIV infection. Number 234, May 2000. Int J Gynecol Obstet 2001; 73: 279-81.

11. Federal Government of Nigeria. Prevention of mother to child transmission of HIV (PMTCT), Nigerian curriculum. Trainers' manual. Federal Ministry of Health. 2006.

12. Federal Government of Nigeria. National Guidelines on Prevention of mother to child transmission (PMTCT) of HIV in Nigeria. Federal Ministry of Health. 2005.

13. Geetha Shivamurthy, Ravindra Pukale, Rashmi Mankhani. "A Prospective Study of Obstetric and New Born Outcome in a Cohort of HIV Affected Pregnant Women". J of Evolution of Med and Dent Sci 2015; Vol.4 (04); 514-524.

14. Wise J. Breast feeding safer than mixed feeding for babies of HIV mothers. Br Med J 2001; 322: 511-13.

15. Newburg DS, Viscidi RP, Ruff A, Yolken RH. A human milk factor inhibits binding of human immunodeficiency virus to CD4 receptor. Pediatr Res 1991; 31: 22-8. 


\section{ORIGINAL ARTICLE}

\section{AUTHORS:}

1. K. Saritha

2. P. Himabindu

3. G. L. Shobitha

4. M. Vasudha

\section{PARTICULARS OF CONTRIBUTORS:}

1. Associate Professor, Department of Obstetrics \& Gynaecology, Siddhartha Medical College, Vijayawada, Andhra Pradesh.

2. Associate Professor, Department of Obstetrics \& Gynaecology, Siddhartha Medical College, Vijayawada, Andhra Pradesh.

3. Assistant Professor, Department of Obstetrics \& Gynaecology, Siddhartha Medical College, Vijayawada, Andhra Pradesh.

\section{FINANCIAL OR OTHER}

COMPETING INTERESTS: None
4. Post Graduate, Department of Obstetrics \& Gynaecology, Siddhartha Medical College, Vijayawada, Andhra Pradesh.

\section{NAME ADDRESS EMAIL ID OF THE CORRESPONDING AUTHOR:}

Dr. K. Saritha,

Plot No.15, Indian Airlines Colony, Opp. Football Grounds,

Trimulgherry,

Secunderabad-500015.

E-mail: saritha.kottu@gmail.com

Date of Submission: 19/05/2015.

Date of Peer Review: 20/05/2015.

Date of Acceptance: 02/06/2015.

Date of Publishing: 06/06/2015. 